\title{
THE 2003 MONEY LAUNDERING REGULATIONS
}

For almost the last four years, considerable attention has focused on the provisions now contained in the Proceeds of Crime Act 2002. In June 2000, the Performance and Innovation Unit of the Cabinet Office produced its report, "Recovering the Proceeds of Crime", which introduced in the U.K., for the first time, proposals to recover civilly assets believed to be linked to crime but which could not be proven to be such to the criminal standard. In parallel with this, new taxation powers were also proposed: both this and civil recovery later appeared in the Proceeds of Crime Bill, now the 2002 Act. The Act also, of course, both simplifies and widens the money laundering regime. All of these measures have, since their inception, rightly been the subject of debate, both in conference presentations and indeed in books and academic articles. Considerably less attention has, however, been paid to a separate collection of anti- money laundering measures, drafted not long after the 2002 Act and which arguably have an equally great, if not greater, impact on the financial services industry. These are the Money Laundering Regulations 2003. It is perhaps worth recalling in passing, incidentally, that the Regulations are not produced by a financial regulator but are secondary legislation, a Statutory Instrument passed by the Secretary of State. As such, a breach of certain of their requirements may result not merely in administrative, but criminal, penalties.

The first Money Laundering Regulations in the U.K. were introduced 10 years earlier, in $1993^{1}$, and came into force on 1 April 1994 . They had as their principal purpose the implementation of the EU Money Laundering Directive and, as such, imposed the regime now often termed "know your customer", together with requirements for record keeping and also training of staff. Like the Directive, they were, however, specifically targeted at the core financial services sector. They were then amended in November 2001, following the terrorist attacks in the United States a few months earlier, primarily to bring within their scope bureaux de change and money transmission offices, which had previously not been covered. They have now, however, been superseded by the Money Laundering Regulations 2003, the bulk of which came into force on 1 March 2004. As with the 1993 Regulations, the principal purpose is the implementation of the EU regime, following the introduction of the Second Money Laundering Directive ${ }^{2}$ at the end of December 2001.

In many ways, the 2003 Regulations build on the 1993 provisions that preceded them, just as the 2001 Directive amends, rather than replaces, the 1991 Directive which preceded it. It is therefore useful to consider first the 1993 Regulations and then the changes which the 2003 Regulations brought about.

\section{Which types of businesses are covered?}

\footnotetext{
${ }^{1}$ S.I. $1993 / 1933$

${ }^{2}$ Directive 2001/97/EC of the European Parliament and Council.
} 
The 1993 Regulations were introduced in July 1993, explicitly in order to implement the 1991 Money Laundering Directive. In their original form, they were specifically addressed to the financial sector: "relevant business" was defined in Regulation 4 as:

- deposit-taking business by banks and building societies;

- wider banking activities as set out in the Annex to the EU Second Banking Directive $^{3}$; the business of credit unions;

- the business of the National Savings Bank;

- investment business as defined in the Financial Services Act $1986^{4}$; and

- insurance business.

On 12 November 2001, however, the Regulations were, as mentioned above, amended by the Money Laundering Regulations 2001 to include money transmission offices and bureaux de change. As with the changes at the EU level, this extension was heralded with considerable publicity: both the Prime Minister, Tony Blair, and the Home Secretary, David Blunkett, proclaimed in the wake of the events of September 11 of that year that they would act swiftly to include bureaux de change in the remit of the money laundering legislation. But as with the similar extension in the 2001 Directive, it is arguable that this was not necessary. The Regulations specifically referred to the list of activities contained in the Second Banking Directive. In the discussion of the antimoney laundering provisions at EU level, this list certainly includes (and included at the time the 1993 Regulations were introduced) money transmission offices and it is arguable that it also includes bureaux de change. As the fight intensifies to disrupt all means of laundering the proceeds of crime, it is certainly important to remove any doubt as to what business are or are not covered: for it merely to be arguable that a given enterprise is covered is no longer good enough, particularly when that type of enterprise has for some time been identified as a popular means of laundering money. But one must also suspect that the 2001 Regulations were also motivated, at least in part, by a desire to be seen to do something, whether or not that something in fact added substantially to what was already in place.

Some debate surrounded the position of lawyers under the 1993 regime. It was clear that they were covered by the provisions relating to the substantive offences in the Criminal Justice Act 1988; these applied to all persons, regardless of their professional position. Similarly, they were covered by the Drug Trafficking Offences Act 1986, shortly replaced by the Drug Trafficking Act 1994; although the obligation to report suspicions of money laundering applied only to those who obtained information, etc. through their work, not to the population at large, this would include lawyers. But, just as lawyers were not included in the scope of the Directive in its original form, it is not clear that they were included in that of the 1993 Regulations. They were certainly not explicitly

\footnotetext{
${ }^{3}$ Council Directive 89/646/EEC. This has since been replaced by Annex 1 of the Banking Consolidation Directive, Directive of the European Parliament and Council 2000/12/EC, although the scope remains the same.

${ }^{4}$ Now a regulated activity under the Financial Services and Markets Act 2000. This term covers, in addition to the former categories of investment business, most forms of financial services activities, including those of banks, building societies, credit unions and insurance companies.
} 
included. In certain circumstances, however, especially where they handle client money, they do engage in investment business or, as now defined, a regulated activity. They certainly give investment advice and may on occasion actually engage in the buying and selling of securities or other investments on behalf of their clients. Under the regime of the Financial Services Act 1986, they were therefore regulated in so doing by the Law Society, designated a Recognised Professional Body (RPB). Although the system of RPBs has passed with the coming into force of the Financial Services and Markets Act 2000, solicitors ${ }^{5}$ continue to be authorised to carry on such business, and regulated accordingly, by the Law Society; that said, the Financial Services Authority reserves the right to impose direct regulation should it ever consider it necessary. ${ }^{6}$ For the time being therefore, the Law Society's Guide to Professional Conduct contains detailed and explicit rules, very similar to those in the Regulations, with which solicitors are required to comply. Unlike the Regulations themselves, however, breach of these rules does not carry criminal penalties. It does, however, carry such sanctions as a severe fine (albeit a regulatory one) or, worse, suspension, or even termination, of permission, not only to engage in a regulated activity but to practise as a solicitor at all.

Nonetheless, with the 2003 Regulations, such doubts are removed. Regulation 2(2) sets out the types of business which are covered; sub-clause (l) refers to "the provision by way of business of legal services by a body corporate or unincorporated or, in the case of a sole practitioner, by an individual and which involves participation in a financial or real property transaction”.

The description of lawyers seems at first glance quite extensive. This may be explained, however, by the variety of ways in which solicitors now operate their business. They may not act as corporations and therefore, historically, law firms have operated as partnerships. This article is not the place for a detailed consideration of English company law; suffice to say that, while a company is a separate legal entity, distinct from its directors and officers, a partnership has no such separate legal personality. Rather, it is one with the partners, who are jointly and severally liable for any wrongdoing, whether in contract or in tort, that the firm may commit. Many, probably even most, English firms of solicitors continue to operate in this manner. In addition, there are certain sole practitioners, as has been the case for many years.

In 2000, however, the Limited Liability Partnerships Act was passed. This created a new type of corporate entity, the limited liability partnership (LLP), modeled in large part on that found in certain U.S. states (notably Delaware) and, more recently, in Jersey. The LLP, in essence, maintains the essential features of a partnership, ie. the partners have a considerable joint stake in the running of the firm in a way that company directors do not, but introduces some of the exemption of personal liability for the firm's wrongs and debts

\footnotetext{
${ }^{5}$ Unlike solicitors, barristers do not handle client money or other assets. They are therefore not authorised to engage in investment business in the same way.

${ }^{6}$ Although it received Royal Assent in June 2000, the substantive parts of the Act, introducing the new regime, only came into force on 3 December 2001. Issues such as under what circumstances the FSA might cease to authorise professional bodies, such as the Law Society and the Institute of Chartered Accountants of England \& Wales, to regulate investment business by their members have therefore yet to receive a clear answer.
} 
that is found with a company. To date, relatively few solicitors' firms have adopted this new form, but those that have are among some of the largest in the City of London, including Clifford Chance and Mayer Brown Rowe \& Maw. It was therefore necessary, when that part of the Regulations relating to lawyers was drafted, for the wording to be particularly wide, so that all forms of law firms would be covered.

But lawyers are far from the only professional group to be brought within the scope of the new Regulations. The term "relevant financial business", used in the 1993 Regulations, is changed to the simpler "relevant business". This is a clear indication, if one were needed, that it is no longer merely the financial services sector and businesses allied to it that are targeted. This sector is, of course, still covered. All businesses included in the 1993 term "relevant financial business" remain included under the 2003 Regulations. The reference in the 1993 Regulations to the Second Banking Directive has been updated to refer to the Banking Consolidation Directive ${ }^{7}$, which replaced it in 2000, but the effect is substantially the same. Further, as seen above, the reference to lawyers is explicitly linked to financial transactions, although equally to real property transactions, for reasons considered below. Together with bureaux de change, money transmission agents are given particular attention: it is not only those who transmit money itself who are covered but those "transmitting money (or any representation of monetary value) by any means". They are also covered separately to the reference, in Regulation 2(2)(e), to Annex 1 of the Banking Consolidation Directive, in contrast to the approach of the amended Money Laundering Directive, which merely emphasises them as an example of those covered by that Annex.

Similarly, businesses which cash cheques are covered. These are not referred to in the Directive, but they are an important sector in the U.K. Although it is probable that most adults in the U.K. now have a bank account, not all do. It is also the case, of course, that a person might have a bank account but, for a variety of reasons, not wish to pay a given cheque into it. Some of those reasons may be legitimate: for example, the banks may be closed and the person wishes to have spending cash now. Others may be less so: apart from the traditional money launderer, there is the person who has earned the money legitimately but wishes to evade paying tax on it. Under the new regime of the Proceeds of Crime Act 2002, however, such a man will be just as much of a money launderer as the drug dealer: tax evasion is a criminal offence in the U.K. and the extra money which results from it, ie. the tax that is successfully evaded, is therefore the proceeds of criminal conduct. Another example will be the man who wishes to hide some of his wealth from those seeking to assess his assets for the purposes of a maintenance order, athough he will be solely a civil offender, not a criminal. There is therefore a sector, often overlooked but present in every major city, of small offices which will cash a cheque as a one-off transaction for anyone who walks in off the street. They make their profits from charging a commission or fee for this service; operating in a very similar manner to the bureaux de change. Indeed, some offer both services. They will be covered by the new Regulations just like other branches of the financial sector.

\footnotetext{
${ }^{7}$ Directive 2000/12/EC of the European Parliament and Council, as last amended by Directive 2002/87/EC of the European Parliament and Council.

${ }^{8}$ Regulation 2(2)(d)
} 
But the list of business goes on, extending well beyond the financial services industry. Accountants and auditors are now covered. Unlike the position with lawyers, this does not merely apply in relation to certain types of clients: all accountancy and auditing business is covered. ${ }^{9}$ So are a range of businesses, included in the 2001 amendments to the Money Laundering Directive, which clearly fall well outside the financial services sector, but have nonetheless been identified as vulnerable to money laundering: estate agents, casinos, dealers in high value goods, etc. The application to dealers in high value goods is, however, limited in precisely the same way as in the Directive: those who deal, for cash, in goods with a value of $€ 15,000$ or more. ${ }^{10}$ This approach has decided disadvantages. It means that, if a person walks into a jewellers and buys a pendant worth $£ 12,000$ and pays for it in cash, the jeweller will be required to go through the full antimoney laundering procedures. But if that person buys the same pendant with a Visa card, even one issued by a bank located in a jurisdiction on the FATF "black list" of NonCooperative Countries and Territories, the Directive will not apply. Nor will it apply if another customer walks in and sells a diamond necklace, very possibly acquired in a third country, to the jeweller and is either paid by a cheque or receives one or more other pieces of jewellery in exchange.

As just mentioned, this is the line taken by the 2001 Directive. But this is itself no reason why these drawbacks should be incorporated into the U.K. legislation. It was open to the Treasury, when implementing the Directive, to address this issue. It chose, however, not do so. Consequently, the issue needs to be addressed now. The problem is, of course, equally real in the context of the EU Directive. Amending an EU Directive, however, although not impossible (this is, after all, what the 2001 Directive does), is a time consuming process, all too often subject to political negotiations that may or may not be directly linked to the matter at hand. ${ }^{11}$ In contrast, amending a U.K. Statutory Instrument, which is what the Money Laundering Regulations are, is a rather simpler process. It does not even require the full process involved in passing an Act of Parliament: it is the Secretary of State, in this case the Chancellor of the Exchequer, or in practice his Department, that is responsible for issuing it.

The Regulations should apply in full to those dealing in high-value goods irrespective of how those goods are paid for: a credit card is not necessarily a greater indication of probity than cash. It is right to preserve a threshold: it is not only burdensome but clearly unnecessary to undertake a full customer identification check in respect of a $£ 50$ necklace. But it is questionable that it is appropriate for that threshold to be $€ 15,000$. Firstly, for the time being at least, the United Kingdom is outside the euro-zone. This is not a political point, it is a practical one. It is not bankers or other financial professionals well used to dealing in euro, and indeed other foreign currencies, who are required to deal with these requirements, it is jewelers and other high value dealers on the ground. There

\footnotetext{
${ }^{9}$ Regulation 2(2)(j) and (k).

${ }^{10}$ For a further discussion of high value dealers, see below.

${ }^{11}$ It was, for example, widely reported that John Major's support of Germany in its call for EU recognition of the new states of Slovenia and Croatia in 1991 was directly linked to Germany's agreement to the U.K.'s right to opt out, in the Treaty of Maastricht, of the provisions relating to economic and monetary union.
} 
is therefore a strong argument that the threshold which decides whether or not the Regulations apply to a given purchase or sale, irrespective of whether or not the transaction appears suspicious, should be in the currency of the dealer, ie. sterling. The first quarter of 2004 saw a marked and really quite swift fall in the value of the U.S. dollar: a sterling amount which was well below US\$15,000 on 1 December 2003 might have been above it on 1 March 2004. Were the euro to undergo a similar fall, a jeweler who up to that point had had no need to monitor the exchange rates, could suddenly find himself not complying with the Regulations - and liable to a heavy fine or, where the breach consisted of failure either to institute anti- money laundering training or to obtain customer identification, up to 2 years' imprisonment.

It could be argued that expressing the threshold in euro does ensure that the Regulations will always properly implement the Directive, something which the U.K. Government is legally obliged to do. But this can be achieved by the Regulations setting a threshold substantially below the $€ 15,000$ limit. In any case, particularly where cash transactions are concerned, it is submitted that a threshold of $€ 15,000$ is too high in any event. This point is discussed at length below. It is therefore suggested that dealers in high-value goods should be dealt with under the Regulations in the same way as any other business sector to which they apply, with the exception that a relatively low sterling amount should be set. One possible approach would be to set a threshold of $£ 1,500$ where the transaction is in cash and $£ 8,000$ (which is unlikely, even with exchange rate fluctuations, to equal more than $€ 15,000^{12}$ ) where it is with a credit card or some other non-cash means of payment. This is admittedly not ideal. Having one rule for cash and another for non-cash payments has decided drawbacks. Credit cards from certain non-EEA banks may be no "cleaner" than cash. Nonetheless, demanding identification in relation to a $£ 1,500$ credit card purchase is going too far. It would have definite advantages, not least creating a substantial obstacle to credit card fraud. But, particularly in a country where, again for the moment, at least, it is not a requirement for persons to carry a national identity card, the inconvenience that it would involve is too great. Furthermore, cash transactions are different in kind to those with a credit card: the differences are considered below in the context of when other professionals are and are not required to obtain identification of those with whom they do business.

Another sector which is not covered, at least not explicitly, by the Directive but does lie within the remit of the new Regulations is insolvency practitioners, as defined in either section 388 of the Insolvency Act 1986 or its Northern Ireland counterpart, Article 3 of the Insolvency (Northern Ireland) Order 1989. ${ }^{13}$ It could be argued that, by the nature of their work, they come within the category of legal professionals (it is to be noted that nowhere does the Directive use the term "lawyers" ${ }^{14}$ ) who assist their clients in "the

\footnotetext{
${ }^{12}$ In any case, were the euro to devalue to such an extent, it is likely that the threshold set in the Directive would be raised.

${ }^{13}$ Regulation 2(2)(h)

${ }^{14}$ The term "legal professional" is of course a convenient term for use in an EU Directive, since each Member State uses different specfic terms to denote its legal profession or, in some cases, professions: "solicitor", "barrister", "Rechtsanwalt", "abogado", "dikigoros", etc. A comparison may be drawn with the use, in the EC Treaty and elsewhere, of the term "undertaking" to cover all the various commercial entities under the laws of the different Member States: limited liability company, Aktiengesellschaft, société
} 
buying or selling of ... business entities" or by the "operation or management of companies or similar structures" as listed in Article 2a(5)(a)(i) and (v). But, as with the inclusion of money transmission offices, they are included separately in order to avoid any doubt that might in turn lead to a time-consuming and expensive test case.

\section{What are the requirements?}

Having established to whom they apply, the Regulations then set out a number of procedures and measures which institutions and persons must adopt in order to prevent money laundering. Under the 1993 Regulations, these were customer identification, record keeping and training. These are retained under the 2003 Regulations and remain the core requirements. Since most transactions will in practice be carried out by institutions or businesses, albeit through a member of their staff, they are described in the following discussion as referring to institutions. It should, however, be stressed that they applied, and still apply, equally to individuals, who may be held personally liable. Indeed, the extension of the scope of the Regulations to what are typically smaller businesses, such as bureaux de change, money transmission offices, jewelers, and also the explicit reference to lawyers and accountants who are sole practitioners, perhaps makes this more important than ever.

\section{$\underline{\text { Identification }}$}

The requirement for customer identification, often referred to as the "know your customer" or "KYC" rule, is perhaps the most familiar; it is certainly the one most frequently discussed. The institution must require from the customer "satisfactory evidence of his identity". ${ }^{15}$ Alternatively, it must take such measures as will produce such satisfactory evidence of identity. This requirement is virtually unchanged since 1993: it is, however, now emphasized that the institution must have set procedures in place. This must be done as soon as an approach is made to enter into a business relationship, or at least as soon as is reasonably practical thereafter. ${ }^{16}$ The new Regulations emphasise this: it is not once the business relationship is actually formed that identification is to be obtained, but when at the first approach. Any doubt as to this is dispelled by the reference, in Regulation 4(1)(b), not to "a customer" but to "an applicant for business". This is entirely in keeping with the timing referred to in paragraph (3)(a): "as soon as is reasonably practicable after contact is first made" between the institution and the prospective customer.

That said, the Regulation does presume that the creation of a business relationship is under consideration: paragraph (2) states, "This Regulation applies if A and B form, or agree to form, a business relationship”. But this will be some time after the first contact.

anonyme, société à responsabilité limitéé, naamloze venootschap, etc. But it also means that certain professionals are arguably included even though they are not "practising lawyers" in the traditional sense.

${ }^{15}$ Regulation 4(3)

${ }^{16}$ An exception applies to casinos, which are governed by a separate requirement: see below. 
When, therefore, is the institution actually expected to ask for identification? This is an important question since identification is defined as one of the most important requirements of the entire Regulations, with a prison sentence available for its breach. ${ }^{17}$ It is arguable that the answer is not entirely clear: the reference to an agreement to form a business relationship on the one hand, and then, a few lines later, to the first contact on the other do appear to conflict. The wise practice would, however, appear to be that the precise moment at which identification is asked for should be guided by circumstances and that this should be recorded in the institution or business' procedures.

Some types of business, by their very nature, involve the setting up of a business relationship with every customer. Lawyers and accountants are examples: the lawyer or accountant provides services to his / her client over a period of time. Indeed, lawyers are typically paid not for the work done per se (the length of the document, the advice, etc.) but by the amount of time they take to do $\mathrm{it}^{18}$, itself a good indication of an ongoing business relationship. Such businesses will be wise to ask for identification at the first meeting with the customer; indeed, many lawyers do precisely this. Others, however, do not: many customers may seek merely one-off transactions. This will even apply to banks: alongside their main customers, with whom an ongoing business relationship will of course exist, will be, particularly at certain times of the year, a not inconsiderable number of persons who hold no account with the bank, nor who have any wish to do so, who simply wish to make use of its bureau de change service. But it will apply even more to dealers in high-value goods, such as jewelers and car dealers, the majority of whose customers make one-off purchases, rather than having any kind of continuing relationship. In such cases, it would seem reasonable for the institution to establish first what kind of business the customer is seeking and then, if it becomes clear that an ongoing relationship is involved, at that point ask for identification.

Certain one-off transactions, however, will also trigger the requirement for identification, although by no means all will. Where this is the case, the 1993 Regulations required that evidence of identity must be obtained before the transaction takes place. This has now been changed: the same timing now applies as with the commencement of a business relationship.

In general, the obtaining of customer identification in relation to an ongoing relationship will mean that it need not thereafter be obtained in relationship to each and every transaction with or on behalf of that customer. Similarly, where a one-off transaction has a relatively small value, the counterparty will not need to be identified, even if there is no previous relationship. The term "customer" is no longer appropriate: the wording of the Regulation refers to two persons, referred to as "A and B", undertaking business and refers to identification being required where a payment above a certain threshold "is to be made by or two B”. As seen below, this will not only extend to customers but also, for example, suppliers.

\footnotetext{
${ }^{17}$ Most of the requirements are enforced merely on pain of an administrative penalty: Regulation 20(1).

${ }^{18}$ There are exceptions: certain "standard" services, such as drawing up a simple will or swearing an affidavit, will often carry a standard charge without any reference to the clock.
} 
The threshold laid down is $€ 15,000$, as laid down in the Directive. This level was prescribed in the 1993 Regulations and has not been changed, just as the 2001 Directive did not alter the EU requirements in this respect. That this requirement is a direct implementation of the Directive may be seen by the fact that, although the Regulations are UK national legislation, the threshold is stated in euro, not a sterling equivalent. This is perhaps especially noteworthy given that the original Regulations were introduced in 1993, when the Conservative Party was in office and moreover had very recently obtained an opt-out from the EU's provisions in the Treaty of Maastricht for economic and monetary union. It may, however, as discussed above, simply be a practical means of ensuring that a fluctuation in exchange rate could not result in the U.K. suddenly finding itself in breach of its obligations under the Directive. The same result could, of course, have been achieved by setting a threshold lower than that actually required. But this in turn would have imposed additional burdens on the financial insitutions, who already frequently express the view that the task of combating organised and economic crime falls too heavily on them. It would certainly not have been popular, nor would it have appealed to a Government and party generally sympathetic to the needs of the business community.

There is, of course, the point, considered above in relation to dealers in high-value goods, that it would be preferable for monetary thresholds prescribed in U.K. regulations to be stated in the national currency, ie. sterling. This may be countered, however, with the point that, unlike jewelers and the like, the other business sectors covered by the Regulations are generally well used to dealing in foreign currencies, including the euro; indeed, they need to keep up to date with the current exchange rates in order to carry on their business. This is clearly true of financial institutions (bureaux de change most of all!) and many of the others are arguably linked to the financial services sector: lawyers, accountants, auditors, tax consultants, insolvency practitioners and the like. An exception is casinos, but, as seen below, the Regulations contain special provisions in relation to these, which do not refer to a monetary threshold.

Where the transaction involves more than $€ 15,000$, however, evidence of the customer's identity must be obtained. This will apply even if it has already been obtained due to the previous forming of a business relationship. There has been substantial criticism of this over time from the financial services industry as it means that, where major commercial clients are concerned, identification will need to be obtained on a fairly regular basis: $€ 15,000$ is a perhaps a not inconsiderable sum for many individuals, but, at approximately $£ 10,100$, it is a relatively small one in the context of a business transaction. The impact on other sectors should also not be overlooked. With a jeweler, for example, most of the customers will, as discussed above, tend to undertake one-off transactions, but ongoing business relationships will exist with the suppliers. Gold, silver and assorted gemstones will need to be purchased on a regular basis and these will swiftly amount to more than the $€ 15,000$ limit. Car hire firms need to replace their cars on a regular basis (it is rare for a hire car to be more than 1 or 2 years old) and each replacement order will involve a payment of well over $€ 15,000$. Yet, as the Regulation stands, each and every time a payment is made or ordered to or from such suppliers, satisfactory evidence of their identity must be obtained. 
Another sector on whom this approach will place a considerable burden is real estate agents. Another, which should therefore perhaps also be dealt with differently to the other sectors, is real estate agents. In practice, almost any piece of real estate bought or sold in the U.K. today will have a value well above $€ 15,000$ : there may be exceptions, such as small properties in areas which are relatively depressed economically, but, on a national scale, these are exceptions. The result, therefore, is that an estate agent will be required to obtain identification from a customer when that customer first registers, since this is the approach to a business relationship and then, if they successfully buy or sell the property on behalf of that client, be required to obtain identification again, very possibly a matter of months later. This would seem both cumbersome and unnecessary and it is suggested that another solution be found.

While the requirement to obtain further identification in respect of transactions above $€ 15,000$ poses an unnecessary problem in respect of general business, at the same time, it is arguable, to say the least, that the threshold is too high for one-off cash transactions. At a time when legitimate consumer business uses cash less and less and other means of payment (debit / credit cards or sometimes cheques) more and more, it is strange that the threshold to trigger an automatic identity check should be around $£ 10,000$ to $£ 11,000$. True, this is the limit set by the Directive and in the Regulations as drafted, the U.K. Government therefore complies with it. But is the fact that the Directive is flawed an adequate reason for the implementing national legislation to be flawed as well.

Nowhere is this more true than of bureaux de change. Conducting on-the-spot observations, the author recently found that a number of High Street bureaux de change, while they required a passport where foreign currency was purchased using a credit card, did not do so where it was purchased with cash. This included the bureau de change counters of banks, none of which, incidentally, required that a person changing currency be a customer of the bank in question. ${ }^{19}$ One was left with the definite suspicion that credit card fraud was viewed as a more significant problem than money laundering. Yet from 2001, at least, bureaux de change have openly been stated as particularly vulnerable as conduits for money laundering. ${ }^{20}$

Cash transactions have a further distinguishing feature: they involve no identification at all. Where a credit card is used, that card is, at least prima facie, a form of identification (indeed, for certain purposes, a credit card often acts as such.) Certainly there have been many cases where cards have been stolen or cloned and then used but then it is far from unknown for passports to be obtained fraudulently, or indeed simply forged. ${ }^{21}$ Besides, there remains a difference between a form of identification which may not always be $100 \%$ reliable and no identification whatsoever. Given, therefore the increased

\footnotetext{
${ }^{19}$ Indeed, it is in the nature of this kind of business that a bank would find it difficult, if not impossible, to do so.

${ }^{20}$ For example, by U.K. Prime Minister Tony Blair, in his announcement of the 2001 Money Laundering Regulations.

${ }^{21}$ See below.
} 
anonymity of cash transactions, it would seem not unreasonable for a lower threshold to apply to them for the purpose of a mandatory identification check.

In this context, it should be recalled that not all money laundering is large-scale. Some, of course, is: considerable study and indeed publicity has been given to the sham corporations laundering vast sums of money. But even the most serious crimes have small-scale aspects. Those participating in the trade in illegal drugs include the barons with their multi-million dollar fortunes but also the street dealers. If the street value of a hit of heroin or crack cocaine is around $£ 20^{22}$, those from whom the users buy directly are unlikely to be handling (and hence laundering) sums of $£ 10,000$ or $£ 11,000$ at any one time. That when the 2003 Regulations were drafted, it was recognised that laundering can be of relatively small amount is clear from the provisions relating to record keeping

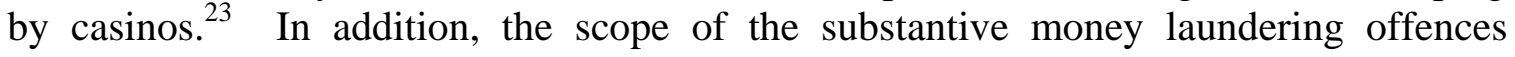
contained in the Proceeds of Crime Act 2002 covers not only the proceeds of an indictable offence, as under the previous legislation, but those of any criminal offence, even one triable only summarily (and hence relatively minor). If attention is now to be paid to the proceeds of all offences, no matter how small-scale, it should follow that the identification threshold should be correspondingly low in cases of one-off transactions of a type which, because of its very nature, means that the customer leaves least of a trace.

Some might argue that a low threshold for cash transactions would be unworkable in practice. This need not, however, be the case. In relation to casinos, historically seen, like bureaux de change, as a business sector vulnerable to money laundering, the Directive provides that where customers purchase or sell chips, the threshold for identification is lowered to only $€ 1,000$, currently around $£ 660$. A threshold quite as low as this might be impractical for all cash transactions, but certainly one of $£ 1,500$ might not be unreasonable. In addition, it could be required that evidence of identity be obtained in all cases where a customer buys or sells foreign currency. Should such a provision be introduced, it could include a partial exemption for banks where the customer holds an established account with them. A draft of such a provision, using the terminology of the Regulations, could begin with a paragraph (1), laying down the general requirement in relation to currency exchange, but preface it with "Subject to paragraphs (2) and (3) ...” Paragraph (2) would then read:

"Where:

(a) a business relationship already exists between A and B and in consequence A has already obtained satisfactory evidence of B's identity; and

(b) the value of the currency to be exchanged is less than 15,000 euro,

further evidence of B's identity need not be obtained by A."

Paragraph (3) would state that subsection (2) shall not apply where A knows or suspects that $\mathrm{B}$ is engaged in money laundering.

\footnotetext{
${ }^{22}$ Source: Metropolitan Police, March 2003.

${ }^{23}$ See below.
} 
It is, of course, well-known that any threshold can all too easily be circumvented by the practice of smurfing, ie. dividing a large transaction up into several smaller ones in order to slip under the radar of the anti- money laundering measures. Regulation 4(2)(c) therefore imposes the same requirement for identification where there are two or more one-off transactions, each of which itself involves less than $€ 15,000$ but which in total amount to more than this and it appears to the person handing the transaction, either at the time or subsequently, that they are linked.

Finally, evidence of identity must be obtained where the person handling the transaction knows or suspects that the transaction involves money laundering. The 1993 version of this rule was somewhat complex in its wording, referring to a knowledge or suspicion either that the customer was himself engaged in money laundering or that the transaction was carried out on behalf of someone who is so involved. The new wording is much simpler: "A knows or suspects that the transaction involves money laundering",24, a welcome step.

The requirement goes to the heart of the institution's role as informant for law enforcement. Even in 1993, when the original Regulations were introduced, a person was obliged, if he executed a transaction which he knew or suspected to be linked to money laundering, to report his suspicions to law enforcement. Now, under the Proceeds of Crime Act 2002, such a report must be made even if the transaction is not in fact executed: the option of telling the prospective customer politely that he should take his business elsewhere and then washing one's hands of the matter is no longer available. The greater the detail that such a report contains, of course, the greater the assistance it provides to those to whom it is made. Suppose, for example, that a bank reports that a man came in and wished to change a large sum of sterling cash into euro and, moreover, specifically requested high denomination notes. ${ }^{25}$ The person approached by this wouldbe customer suspected that such a large sum of cash could well be linked to crime and the desire to change it into $€ 500$ notes only confirmed the suspicion. But because they suspected that this was an attempt at money laundering, they refused to process the transaction and sent the man away. They then sent a report to the National Criminal Intelligence Service, informing them of this. Such a report will reassure law enforcement that the bank has not taken part in money laundering, but will do absolutely nothing to assist them to find the man with the large amount of cash and ascertain what he and his associates may be up to. It is therefore important, from a law-enforcement perspective, that the institution be able, in its report, at least to provide the suspicious customer's identity.

\footnotetext{
${ }^{24}$ Regulation 4(2)(b)(i)

${ }^{25}$ This is, of course, a fanciful example: money laundering today is a far more sophisticated affair than this. It does, however, serve to make the point. In any case, banks are now wary even of changing medium denomination sterling notes into higher value ones: when I recently asked the branch of Barclays Bank on Russell Square to change $£ 300$ in $£ 20$ notes into $£ 50$ notes, the cashier refused, explicitly stating that this was to guard against money laundering.
} 
An exception to the above rules is provided in the case of casinos. These have long been recognized as being particularly well-suited to money laundering. There have, of course, been the cases, widely reported, where casinos have been found actually to be owned and operated by criminal organizations, but even where the management is honest and lawabiding, the frequent changing of large amounts of cash into chips and back again is ideal for those who wish to disguise the source of the money. ${ }^{26}$ To counter this problem, the Directive provides, as a minimum requirement, that casinos therefore obtain evidence of the identity of customers where they buy or sell chips to a value of $€ 1,000$ or more. This is, however, an unsatisfactory response, since in a casino, smurfing is at the same time very easy to achieve and very difficult to detect and prevent. The U.K., in its new Regulation 8, therefore adopts the rather more productive option, also provided for in the Directive, of requiring casinos to obtain satisfactory evidence of identity of all customers before they are allowed to use the facilities. It is to be hoped that this will become the model across the EU.

A further exception pertains to insurance business: this is directly copied from the corresponding provision in the Directive and states certain types of, in particular, life assurance policies are exempt where the premium is below a certain amount and, furthermore, the policy cannot be cashed in.

Under the 1993 Regulations, there was a provision that, where payment is made either by post or by some electronic means and, further, it is reasonable for it to be made in this way, the fact that the payment is to be deducted from the customer's account at a bank or building society will constitute satisfactory evidence of the customer's identity. There was a safeguard that the institution concerned must be regulated either by the Bank of England (later the Financial Services Authority) or the corresponding banking supervision authority of another EEA Member State. This was all very well, but it did not assist the institution either in face-to-face transactions or when setting up an account. It also creates a serious problem for law enforcement: the loophole that a person may make a payment from a bank regulated by an EEA Member State either with a regulatory record that is not as good as it might be or, worse, one with a reputation for shielding money launderers. This provision has therefore been removed, although the 2003 Regulations do, as discussed below, provide for certain other exemptions from the identification requirements.

It will sometimes occur that the institution has reason to believe that the client with whom it is dealing is not operating not on his own account but on behalf of a third party. In such a case, the institution is to take reasonable measures to establish the identity of the true beneficiary of the account, or transaction as the case may be. ${ }^{27}$ This in itself is fairly uncontroversial, but what constitutes "reasonable measures" is not clarified. The 1993 Regulations provided that these were to be judged firstly by the circumstances and

\footnotetext{
${ }^{26}$ In Macau, until recently a territory of Portugal and hence of an EU Member State, this has been taken a stage further with persons, often money launderers, offering chips to customers at a discounted rate. (Source: Paper delivered at the Twenty-First Cambridge International Symposium on Economic Crime, September 2003.)

${ }^{27}$ Regulation 4(3)(d)
} 
secondly by the best practice followed at the time and in the business sector in question. What constitutes "best practice" may itself be a matter of debate: a large institution may be able to take different measures to those which are practical for a smaller institution in the same sector. The 2003 Regulations therefore state that, when deciding whether or not the identification requirements (and, indeed, certain other requirements) have been breached, a court must have regard to whether or not the defendant business person followed any relevant guidance in force at the time in question. This guidance may be issued by "a supervisory authority", in practice the Financial Services Authority, and must both be approved by H.M. Treasury and published in a form in which the Treasury approves. ${ }^{28}$

Separate to this, the business person may accept a written assurance from the client that evidence of the identity of any principal for whom that client may be acting has been obtained and recorded under the procedures which they maintain as part of their business practice. ${ }^{29}$ Certain conditions are, however, attached. Originally, it was required that the institution $^{30}$ must, however, still follow the general best practice in its sector. This reference to best practice has now been removed. Secondly, the client in question was required to be a financial institution: this has remained. In such cases, the client must either be a person or institution subject to the U.K. Regulations or to provisions, implementing the Money Laundering Directive, of another EU Member State. Or, alternatively, regulated by an overseas authority and based or incorporated in a country outside the EU but which has in force provisions at least equivalent to those of the EU Money Laundering Directive. This latter provision has been retained, essentially in its 1993 form. $^{31}$

The identification required is described as "satisfactory evidence of identity". The Regulations are no more specific than the Directive, however, as to what is held to be "satisfactory". This was the case with the 1993 Regulations; it remains the case. No particular forms of identity are prescribed or even suggested. The only guidance is found in Regulation 2(5) and (6). Regulation 2(5) is almost identical to Regulation 11(1) of the 1993 Regulations. It states that evidence of identity is satisfactory if it "is reasonably capable of establishing (and does in fact establish to the satisfaction of the person who obtains it) that the applicant for business is the person he claims to be".

This is hardly much help. It is, in effect, for the person whom the applicant for business approaches to decide whether or not the form of identification establishes who he is - but at the same time, the evidence must be "reasonably capable" of establishing this. What is "reasonable" - and who decides? The problem is all the greater given that the United Kingdom has no standard form of identity. Unlike in most other Member States, there is no national identity card; although one has now been announced, it is not expected to be fully in place until 2007 and, indeed, will not actually be compulsory until later even than

\footnotetext{
${ }^{28}$ Regulation 3(3)

${ }^{29}$ Regulation 5(3)

${ }^{30}$ As discussed above, the 1993 Regulations applied to a rather narrower range of businesses: essentially, financial institutions.

${ }^{31}$ Regulation 5 (previously 10).
} 
that. It will, however, incorporate not only a photograph, as at present, but also a chip containing various data including a fingerprint and eye scan. This, it has been stated, would also permit the holder to travel within the European Union (just as citizens of other EU Member States can already travel to the U.K. on their national identity card rather than a full passport) and it is openly intended to be a major step towards a national identity card. But for some time, it will fall well short of what persons are obliged by law to carry, in all circumstances, in Member States such as France, Germany and Belgium.

There has, however, been considerable suspicion of a full national identity card on the Continental European model. The above plans, like those which preceded them, have met with considerable disquiet from human rights groups and provoked such headlines as "Big Brother fears on identity card". Although we are ever more frequently asked for identification for different aspects of our lives, whether it be opening a bank account, joining the local library or entering the premises of government departments, the U.K. national culture has not been sympathetic to an identity card that can be required by law enforcement on demand. As one person put it, "The point is that in England, we don't have Papiere.” In practice, law enforcement in the U.K.'s fellow Member States do not often demand ID in the street on a daily basis. In many years of travelling throughout the European Union, I have only been asked by police to produce an ID card in this manner in one Member State, Belgium, and even there only twice. But many civil liberties groups would argue that this is simply because I am white, that the experience in France, for example, of someone who is black or Arab is very different. In the black communities in the U.K., too, the memory of the "sus" laws causes distrust of any kind of compulsory identity card.

Separate to this is the question of the information that would be contained on such a card. Because they were introduced at a time when technology was far less advanced, identity cards in most Member States have a relatively limited range of information: name, date and place of birth, current address, nationality, etc. That said, some go further. The German identity card also states such things as nationality and eye colour, while until recently, the Greek card also stated the holder's religion, although it does no longer. This is an extremely important part of the Greek national identity but it is also something which ethnic minorities in Greece claimed led to discrimination and worse. In the U.K., as mentioned above, it has been suggested that the card, if and when it is introduced, should make use of available chip technology to hold a large amount of data: important medical information and details of any criminal convictions, for example. The latter would be a welcome means to control those under a restriction of movement, such as persons on bail or probation, those released on licence or those on a sex offender's register. But some fear that it could also lead to a past offender being harassed by the police, even though he is quite entitled to be where he happened to be stopped. The former, although invaluable in an emergency, could well, of course, reveal a person's HIV status, again leading to potential harassment. Also, unless the medical information to be contained was very strictly defined, it could hand a person's entire medical records, currently the subject of extremely strict confidentiality, to every law enforcement officer. 
These concerns mean that the debate surrounding the new identity card and the extent to which it is developed, is likely to continue for some considerable time. If and when it is introduced, however, it would seem extremely likely that this card, whether compulsory or not outside the context of the road traffic laws, will become a standard form of identification for the purposes of the money laundering regulations.

Until a card, compulsory or otherwise, is introduced, the U.K. is left with the problem that there is no standard form of identification. A common form cited is a passport. But although many British citizens now travel abroad, a number do not. Then there is the driving licence. This is probably the closest to a standard ID, particularly now that it carries a photograph. ${ }^{32}$ Again, however, although most adults in the U.K. drive a car, not all do. The one form of identification which everyone possesses is a birth certificate. This is, however, a cumbersome document, which few people therefore routinely carry; indeed, many use it so rarely that they do not immediately know where theirs is located. In any case, it contains nothing that enables a person checking it to link it with confidence to the person presenting it. The banks are therefore currently left with a list of forms of identification, one of which must be produced. These include: passport, driving licence, birth certificate, marriage certificate, or Forces Identity Card.

This is well and good but these are as easy, possibly easier, to falsify than a passport. This does not simply mean forging the document (although it obviously includes that), it extends to obtaining a genuine document in a false identity. In the U.K., this was highlighted in January 2003 when Paul Kenyon, an investigative journalist for the BBC, successfully obtained a copy of the birth certificate of the author Frederick Forsyth and then, on the strength of it, obtained a driving licence in the same name. It was then a simple matter for him to open a bank account and obtain a credit card. For good measure, he then, by similar means, obtained a driving licence in the name of the Home Secretary, David Blunkett, despite Mr. Blunkett's being registered blind. That this was no one-off stunt by a journalist is clear. A month later, British pensioner Derek Bond was, with considerable publicity, released from custody after he was found to have been the victim of an identity theft by suspected terrorists in the United States. The ensuing reports cited an estimate that the financial cost of identity theft / fraud currently runs at $£ 1.3$ billion per year in the U.K. alone. ${ }^{33}$ It is one thing for a bank's staff to be trained to look out for forged documents; it is another for them to recognise that a genuine document (ie. one actually obtained from the official department that it purports to be from) is not what it appears to be. Until this issue is addressed, one must question how effective the identity check can in any case actually be.

\footnotetext{
${ }^{32}$ This was far from always the case: long after driving licences in the rest of Europe carried a photograph, that in the U.K. was a simple printed card with only a signature. This only changed when a standard EUformat driving licence was introduced in the 1990s.

${ }^{33}$ The Guardian, 27 February, 2003. The same report states that the U.K. Passport Agency, between April 2000 and March 2001, detected 1,484 fraudulent applications, including 301 involving the identities of persons who were dead and 1,003 simple identity thefts of those still living. Inevitably, these are simply those which were detected: given that few agencies have a crime detection rate of $100 \%$, one can only speculate at how many more such applications were successfully made.
} 
It would be reckless, to say the least, to suggest that any kind of card is impossible to counterfeit, not least since it has long been recognised that criminal organisations all too often have access to rather greater resources, and hence skills and technology, than do governments. It has been stated, however, for some time that the technology is there to make an entitlement card at the very least extremely difficult to counterfeit, certainly more so than, for example, a passport. The problem, outlined above, of fraudulently obtaining identification documents from their genuine, official sources is potentially a greater one, since it could apply as much to the new card as it does to current documents. But it is clear that this urgently needs to be addressed in any event. If the two issues are adequately addressed, an entitlement card could provide the answer to the current search for one, standard form of identification which banks and other financial institutions can use, not only to comply with their legal obligations under the regulations but to create a system which genuinely makes money laundering more difficult.

To date, the move for the introduction of identity / entitlement card has come largely from government. Interestingly, the current discussion has been primarily in the context of asylum seekers (and in particular bogus asylum seekers) and their access to the public services mentioned above. To a lesser extent, it has been discussed also in relation to the detection of terrorists (an issue often linked to that of asylum seekers). The value of an entitlement card in the prevention of money laundering has not generally been discussed, either by government or by the financial services industry. It is possible that this additional argument, particularly if it is raised by the commercial sector rather than government, may go some way to persuade those currently suspicious of such of a card that, in addition to its other benefits, it is rather more a valuable tool to assist and protect our financial institutions than a threat to our liberties and way of life.

An exception to the above concerns transactions on behalf of "money service operators", defined as bureaux de change, money transmission offices and cheque encashing businesses. $^{34}$ These, as is discussed above, have long been viewed as businesses especially vulnerable to money laundering; indeed, many are believed to be criminal enterprises. It was a pledge by the Labour administration in the wake of September 11, 2001 that not only would bureaux de change and similar businesses be brought within the remit of the anti- money laundering provisions but that they would more generally be subjected to strict regulation. As part of this, the 2003 Regulations, as a separate provision, require these businesses to be formally registered with the Commissioners of H.M. Customs \& Excise. ${ }^{35}$ Linked to this, Regulation 2(6) states that, where it is either known or there are reasonable grounds to suspect that the applicant for business is a "money service operator" (ie. a bureau de change, money transmission office or cheque encashing business), their registered number must be obtained as part of the identification check. The registration of money service operators and dealers in high value goods is a separate provision, considered below.

It is, however, recognised that in some cases, the applicant business will not have such a number: it is stated that the satisfactory evidence of identity "must include the applicant's

\footnotetext{
${ }^{34}$ Regulation 2(1), (2)(c)

${ }^{35}$ Regulation 10. The same requirement to register is imposed on dealers in high value goods (as defined).
} 
registered number (if any)". The fact that the business does not have a registered number will not always of itself be a ground for suspicion. Different jurisdictions have different approaches to regulation: not all impose the registration requirement that the U.K. is now introducing. This includes certain EU Member States; the provision is not required by the Directive or indeed any other EU legislation. A situation may therefore well arise where a person or institution engaged in relevant business has reasonable grounds to suspect, or possibly even knows, that their potential client is a money transmission office in another jurisdiction. That jurisdiction may further have a good reputation for financial services regulation in general and anti- money laundering provisions in particular but not require money transmission offices to be registered in the same way that they are in the U.K. Indeed, it may not provide for such registration, even on a voluntary basis: the U.K. is only doing so now. In such cases, it would appear that the U.K. institution will obtain such forms of identity as they consider suitable and, further, note that their potential client does not have a registered number because the jurisdiction where they are located does not require one.

But will that be the end of the matter? In principle, it should be unless there are, separately, grounds to suspect money laundering. Among those grounds may be that the money transmission office is located in a jurisdiction with a poor record for prevention of money laundering, particularly if that jurisdiction appears on the FATF current list of Non-Compliant Countries and Territories. (Where it has been so listed in the past, but has recently been removed, the matter is more complicated, but a prudent institution may well wish to play safe, file a suspicious transaction report and quite possibly decline the business.) But, as is often remarked in the context of money laundering prevention measures, hindsight is invariably 20-20 while foresight, with the best intentions, all too often is not. An institution, or rather its officer who deals with the approach, may well not see any reasonable grounds to suspect that a money service operator, which happens to be based in a jurisdiction which does not require it to be registered, is engaged in money laundering. But should it transpire that the client was in fact so engaged, its lack of registration could all too easily be seized upon by the investigating authorities. The result may therefore be that, in the future, other jurisdictions find themselves compelled to provide for at least voluntary registration in this sector simply in order for their institutions to be able to conduct transactions with those in the U.K. ${ }^{36}$

As noted below, not only money services operators but also dealers in high value goods are required to be registered. In contrast to money service operators, however, satisfactory evidence of the identity of such dealers is not by definition required to include their registration number. That they are treated separately may at first appear a little curious. It may be explained, however, by the fact that dealers in high-value goods, within the terms of the Regulations, are not merely persons (legal or natural) who deal in high-value goods. As seen above, there is an additional proviso that, to be covered by the

\footnotetext{
${ }^{36}$ Professor B.A.K. Rider has in various conference papers repeatedly warned in recent years that the trends in money laundering legislation in jurisdictions such as the U.K. and, even more, the United States could well result in a two-tier world financial system: the countries of the developed world which will be able to trade with each other and the others which will find themselves out in the cold. It may be that this will be one example of this.
} 
Regulations at all, they must conduct, in or for cash, transactions with a value of at least $€ 15,000$. If they do not, they will not need to be registered ${ }^{37}$ and hence will not have a number. It is of course possible for a financial institution to have a reasonable idea as to the nature of their client's business; indeed, if they are remotely to comply with their obligations, not only under the Regulations but under the Proceeds of Crime Act 2002 as well, they must have such an idea. But clearly, it is much more difficult for them to know up to what value their jeweller-client buys and sells articles in cash. The mere volume of cash that he pays into an account will not in itself reveal this. A jeweller with a relatively slow but extremely high value business, who on an average day sells only a few pieces but for a price of $£ 15,000$ or $£ 20,000$ cash each time will need to be registered and will therefore have a number (or at least should do). But another jeweller, who only takes cash for items with a value up to $£ 8,000$ but has a much brisker trade, will be exempt from registration and hence will have no number. It is in order to avoid the financial intermediary being placed in a truly impossible position that the evidence of identity of a money service operator is required to include its registration number, but that of a dealer in high value goods is not.

As with the fact that they are only covered by the Regulations at all insofar as they engage in transactions which not only have a value of at least $€ 15,000$ but moreover are in cash, one suspects that dealers in high value goods, as a sector, are not considered, either by H.M. Treasury or by its counterparts in the other EU Member States, to be particularly vulnerable to money laundering. Whether their assumption is justified is, of course, a matter for debate.

The identification procedures are set out more fully than in the 1993 Regulations, but, as already noted, there are few substantial changes. What should be stressed is that, as before, these are not merely requirements of what the institution is to do: the institution must have written procedures which explicitly contain all of these. The potential customer must be required to produce satisfactory evidence of his identity as soon as is practicable after the business relationship is commenced; alternatively, such measures must be taken that will produce it. It is, of course, essential that the latter option remain open if the institution is to undertake any business at all with customers who are situated abroad - or indeed anywhere from whence it is impractical for them physically to come into its premises. One change is that the procedures are now to require that that where satisfactory evidence is not obtained, the business relation or one-off transaction is not to proceed. $^{38}$ Although this appears to be a new provision, insofar as it has not been stated in such terms up to now, it should be recalled that, even under the 1993 regime, to conduct a business relationship when one had failed to obtain satisfactory evidence of the customer's identity was a criminal offence carrying a prison sentence. The provision is therefore merely a more explicit statement of what was in practice already required.

\section{Record keeping}

\footnotetext{
${ }^{37}$ See below.

${ }^{38}$ Regulation 4(3)(b)
} 
Once the evidence of identity, in whatever current form, has been obtained, it must be kept on record for at least 5 years: ${ }^{39}$ this is as under the 1993 regime. But precisely what must be kept on record is more complex: there are three options. Option 1 is the simplest: a copy of the evidence itself (passport, driving licence or whatever). Option 2, equally permissible, is simply information which would, if necessary, enable a copy to be obtained. Option 3 applies where neither of these is reasonably practical: the record will still comply with the Regulations if it contains "information to enable the evidence of identity to be re-obtained”.

Quite what this may mean is unclear. The wording has been somewhat simplified from the 1993 version, but the essential provision is the same - with all its drawbacks. If it is impractical to comply with the requirement to provide information that will enable a copy of the customer's evidence of identity to be obtained, what kind of information can the record contain that will enable the evidence to be re-obtained? It could be argued to cover the scenario where the institution has required sight of the evidence, eg. a passport, but, having viewed it and considered it satisfactory, has not made a copy of it. But any information which will enable a copy belatedly to be obtained will comply with Option 2 . The only scenario which would appear to fit would be where an institution, instead of taking a copy of the passport or whatever, simply records its details: name, nationality, number, date and place (where appropriate ${ }^{40}$ ) of issue, etc. This would seem to be come within the parameters of Option 3: it enables the evidence of identity to be re-obtained.

Although such a procedure would come within the Regulations, it will generally not be ideal practice. Where possible, the institution (or rather its officer who opens the account or deals with the one-off transaction) should have sight of the client; indeed, the identification procedures required of the business are explicitly to take into account the problems involved in their not doing so. ${ }^{41}$ Even where the client is located abroad, it is not unduly burdensome to request that a copy of an approved form of identity be faxed over to be kept with the records. The exception to this rule, of course, is Internet business (often referred to as e-commerce), an increasingly common feature of the globalised world that financial services business has become. Where the transactions take place online, there is no face-to-face contact, even in the wider sense of a telephone conversation. All the institution can therefore do is include, in the form on which the online client orders the transaction (or opens the account), a section where they complete the details of their passport. The problem with this, of course, is that it is then open to a criminal client to fill out completely fictitious details. The institution has no way of knowing; they cannot even scrutinise the document. Only in the event of a major law enforcement investigation, including the cooperation of the jurisdiction from which the passport purported to be issued, will it ever come to light that the details are false. In such an event, all that anyone will be able to do is freeze whatever funds happen to be held in the account at the time: identifying the client will be close to impossible.

\footnotetext{
${ }^{39}$ Regulation 6

${ }^{40}$ It is to be noted that not all identity documents indicate a place of issue: whereas at one time, a British passport did state the location of the office that issued it (London, Peterborough, Glasgow or whatever), now it merely states "United Kingdom Passport Agency".

${ }^{41}$ Regulation 4(3)(b)
} 
The problem of regulating Internet financial business has for some time been recognised as a thorny one. Numerous books have been written on the subject ${ }^{42}$ and this is not the place to replicate them. Although a number of solutions have been promoted, in both legislation and regulation, their enforcement in practice can often be rather more difficult than the theory. Nonetheless, for the purposes of control of money laundering. nit would seem not unreasonable to require banks and other businesses to obtain at least a copy of the relevant pages of the passport before business could be proceeded with; if need be, this copy can be sent by fax. The copy should further be certified by a legal practitioner, not merely by means of a signature ${ }^{43}$ but also a stamp or other clearly legible details of address. This, it is accepted, is still not an ideal solution. It is recognized that a certain proportion of lawyers are not as honest as they might be: indeed, some have gone to prison for offences of serious dishonesty. But, while not totally effective, it is a substantial safeguard. At the very least, the lawyer concerned could easily be checked against the local Bar / Law Society list before the account is opened or transaction proceeded with.

Of course, the obtaining and recording of the evidence of identity is not the end of an institution's KYC obligations. Although the Regulations do not themselves require more, in practice, considerably greater diligence is expected. An institution which does not maintain a detailed and ongoing KYC mechanism risks an extremely uncomfortable series of interviews, and very possibly the serious charges of the 2002 Act, should money laundering be found to have taken place. Considerable space has, however, been devoted elsewhere to the topic of what constitutes a proper and prudent KYC system; this study is not the place to elaborate further on it.

In addition to the evidence of identity, a record must also be kept, for the same period, of all transactions carried out in relation to the customer's account. With most businesses, this is potentially cumbersome, but not totally impractical. For casinos, however, it is a different matter. Since casinos are now covered by the Regulations, the record keeping rules apply to them as well. As seen above, casinos are required to obtain evidence of identity of all customers, even before they purchase any chips (and hence irrespective of how high or low the value of those chips happens to be) and this can easily be recorded and stored. It is, however, distinctly impractical to ask the casino to keep records of each and every transaction by small-time individuals who gamble perhaps $£ 100$ maximum in a night. In an earlier draft of the 2003 Regulations, therefore, there was a provision that copies were to be kept, not of each and every casino transaction, but only those with a value of $€ 1,000$ or more. An exception was, as usual, made where it is known or suspected that the customer is engaged in money laundering. In such cases, a copy was to be kept of the transaction regardless of how large or small its value, a recognition that money laundering may on occasion involve sums even lower than $€ 1,000$. In the form in which the Regulations entered into force, however, the concession of the $€ 1,000$

\footnotetext{
${ }^{42}$ See, for example, Philip Rutledge \& Jason Haines, Electronic Markets, Butterworths Compliance Series, 2001.

${ }^{43}$ It is far from unknown, certainly in the U.K., for solicitors or barristers who are personal friends simply to hand write a suitable form of words with a signature and nothing more.
} 
threshold for casinos was removed. Each and every transaction will therefore need to be recorded and filed, from that of the wealthy tycoon who gambles millions of pounds to the small fry, merely having an amusing evening, who buys $£ 100$ worth of chips and then leaves. This is not simply a matter of accounting, noting how many chips of what value are bought and sold; it is each customer's transactions that must be recorded and hence the customer's details will need to recorded in each case. It may be suspected that casinos will smother under the weight of paperwork and the concession may be reinstated in future reforms. But for the moment, the records obligation remains in full.

\section{$\underline{\text { Reporting structures }}$}

The Proceeds of Crime Act 2002, like the legislation that preceded it, stipulates that, when a financial institution comes to know or suspect that a client is engaged in money laundering, they are required to report it to the relevant authorities: usually NCIS, but on occasion to any police or customs officer. The procedure is generally, however, that the individual member of staff makes a report not to law enforcement but to a designated officer of the institution, previously referred to as a Money Laundering Reporting Officer (MLRO) but now, since the coming into force of the 2002 Act, as a nominated officer. This structure is no mere chance: institutions are specifically required under Regulation 7 to create such a system. A person must be identified as that to whom employees of the institution report any information, or indeed other matter, that, in their opinion, gives rise to a knowledge or suspicion that another person is engaged in money laundering. That other person will generally be the institution's client, or sometimes merely potential client, but they may also be an officer or employee of the institution itself.

The nominated officer must not only be identified as a conduit for reports, however. On receiving a report from a colleague, he must then weigh it up, together with any other information that he receives, either from the person making the report or from another person, designated for the purpose, in order to decide whether or not it does indeed give rise to knowledge or suspicion of money laundering. The "designated person" is only mentioned in passing in the Regulation. It may refer, however, to a number of persons. Most clearly, it refers to the Compliance Officer. Although the Compliance Officer may in some institutions be one and the same as the $\mathrm{MLRO}^{44}$, this is by no means always the case. The two roles, though linked, are very different. The MLRO's role is to receive reports from colleagues of suspected (or indeed known) money laundering and, if he considers them to be substantiated, to pass them on to NCIS. He will also often be given the role of providing the anti- money laundering training to staff (see below), although this is sometimes subsumed into the general training in regulatory compliance which is the responsibility of the Compliance Officer. In contrast, the Compliance Officer's task is to ensure that both the institution corporately and its individual officers and employees comply with the rules imposed on them both by legislation and by regulatory bodies,

\footnotetext{
${ }^{44}$ The MLRO is now, with the coming into force of the Proceeds of Crime Act 2002, termed the nominated officer. To avoid the possible confusion that may arise between "nominated officer", "designated person" and "compliance officer", however, the term MLRO is retained here for the purposes of discussing the roles and responsibilities of the different positions.
} 
notably the Financial Services Authority. This will include the money laundering regulations, although it is much wider than that. Thus a report of suspected money laundering will go to the MLRO but it will be the Compliance Officer who is asked whether a given transaction should proceed. This latter is a high-pressure task: it is far from unknown for a dealer on a trading floor to expect an answer within 10 seconds.

The reference to the Money Laundering Reporting Officer (or nominated officer) and to the Compliance Officer disguises the fact that, particularly in large institutions, these functions are often not performed by one individual but by entire departments. Thus there will be a Compliance Officer and a number of Deputy Compliance Officers. This is even more true where groups are concerned: in a major financial institution, there will be one or more branch Money Laundering Reporting Officers but then a Regional Money Laundering Reporting Officer, perhaps covering a region, a country or a group of countries, and, ultimately a Group Money Laundering Reporting Officer. The same is true of the Compliance Officer role. The "designated person", to which Regulation 7(a) refers, will cover all of these. A branch MLRO may, in certain circumstances, before deciding whether or not to file a report to NCIS, ask the advice of the Regional MLRO or perhaps ask him whether any previous queries have been raised in relation to that particular client (or client's counterparty).

Conversely, as has been noted above, a number of businesses to which the Regulations apply are in fact sole practitioners. Clearly, it is impractical, to say the least, for a person who neither employs anyone nor works in association with anyone else to have a nominated officer and an internal reporting structure. Regulation 7(2) therefore exempts such persons from this requirement.

Most businesses will, however, be required to have a nominated officer. To enable that officer to assess whether knowledge or suspicion of money laundering is raised, and hence whether or not a report is to be made, the institution is required to give him reasonable access to any information which may be of assistance to him. The paragraph continues, "and which is available to the person reponsible for maintaining the internal reporting procedures concerned". In practice, however, it is the nominated officer himself who is responsible for this; the other information will more often, therefore, be found elsewhere in the institution. Finally, it must be ensured that the nominated officer discloses the knowledge or suspicion to NCIS. The 2002 Act requires the nominated officer to do this in any event; the importance of this provision in the Regulations is that, in addition, the institution's own internal rules and procedures must also require it.

\section{Training}

A further requirement is to provide anti- money laundering training to staff. This is referred to early on in the Regulations, in Regulation 3(1)(c). It is, however, covered here in this study since it is best understood once it has been discussed what specifically the staff are to be trained in. 
Firstly, they are to be trained in the procedures, discussed above, that the institution has in place to prevent money laundering. Secondly, they are to be trained in the current laws and regulations relating to money laundering. This of course includes the provisions of the Proceeds of Crime Act 2002 and the Money Laundering Regulations 2003. But it also includes the rules, as they pertain at the given time, of the Regulatory Handbook of the Financial Services Authority and / or the rules of the relevant professional body: the Law Society or the Institute of Chartered Accountants of England \& Wales.

Thirdly, they are to be trained in recognising transactions carried by, or on behalf, those who are or appear to be engaged in money laundering. This will need to be reviewed on a regular basis. It will include the different methods currently used to launder money: which types of transactions are particularly popular and what kind of investments (not just securities but also trusts, accounts, real property, etc.) are currently used in the intermediate stages. It will also give an up-to-date list of the Non-Compliant Countries and Territories cited by the OECD's Financial Action Task Force (FATF) as being particularly vulnerable to money laundering and give instructions on how to proceed with requests to conduct transactions involving those jurisdictions. In so far as it is possible, this part of the training seeks to impart to the staff the sense required to apply the "smell test". This test, famous in the financial services industry, refers not so much to a particular sign that something is amiss but rather to an intangible sense that all is not well: the transaction "just doesn't smell right".

All this training is to be given to all staff whose duties include the handling of "relevant financial business". This will mean just about everyone except the purely administrative and maintenance staff. In a large institution, this is, however, far from easy. To corral all new staff into a training session at one time will, for the period that the session is in progress, cripple the institution's ability to carry on its business. The practice is therefore to run a number of sessions of which each member of staff is required to attend one. It is not uncommon, however, for the series to end with some staff still not having attended, despite repearted instructions that all are to do so. It is likely that in the future, attending such training, when required, will need to be an explicit term in staff contracts in the financial services sector; for the moment, however, this is rarely the case.

One might have thought that, just as the provisions relating to internal reporting structures take note of the fact that some businesses operate as sole practititioners, so would the training requirements. If a person does not have any employees or associates, precisely whom is he to train? But there is no equivalent exemption. The closest to one that may be found in Regulation 3 is by implication. Paragraph (1)(c) refers to training being required to be provided to "relevant employees"; if there are no employees whatsoever, it may be argued that there are no relevant ones and therefore no one who needs to be trained. It would, however, assist with making the requirements clearer and more straightforward, were an equivalent provision to Regulation 7(2) to be incorporated in Regulation 3.

Detailed though all the above provisions under the Regulations are, it should be noted that the list of requirements is not exhaustive. Regulation 3(1)(b) contains a catch-all 
provision: financial professionals and institutions are additionally required to take "such other procedures of of internal control and communication as may be appropriate for the purposes of forestalling and preventing money laundering." Merely complying with the letter of the various requirements is therefore explicitly stated not to be sufficient in itself.

The Regulations are strict: breach of any of the above requirements constitutes a criminal offence, carrying a prison sentence of up to two years and / or an unlimited fine. ${ }^{45}$ Similarly, where such an offence is committed by a corporate entity but it is proved that this was with the connivance of a director, manager or similar officer, that director or manager will incur personal criminal liability together with the entity itself. The same applies to partners of partnerships, an important consideration for law firms and firms of accountants, which tend to be partnerships, rather than companies of any kind ${ }^{46}$, but which are also regularly cited as industries which fail in their obligations to prevent money laundering. ${ }^{47}$ It is, moreover, made clear that the provision is not confined to persons holding actual authority: they are extended to "any person purporting to act in such a capacity".

\section{$\underline{\text { Registration }}$}

As noted above, money service operators and dealers in high value goods are required, under Regulation 10, to be registered. At present, the registration system is operated by H.M. Customs \& Excise; Regulation 9 requires them to maintain the register while Regulation 10 requires the relevant businesses to register with them. How long this will continue to be the case is, however, unclear. It was announced on 17 March 2004 by HM Treasury that, following a report submitted by Mr. Gus O’Donnell, Permanent Secretary to the Treasury, HM Customs \& Excise and the Inland Revenue were to be merged into a single department. To date, little in the way of detail has been given: one has yet to hear when the merger would take place and what the new department would be called. Nor has it been disclosed whether this new merged entity would retain those functions of HM Customs \& Excise which are not specifically related to the collecting of taxes. Foremost among these is the prevention of the smuggling of goods not on which duty should rightfully be paid but which it illegal to import into the U.K. at all: controlled drugs, arms, pornographic material and the like. But they also include a role in the prevention of money laundering.

For such details, one can, for the moment, only wait. But what would seem clear is that, whichever body supervises it, the registration requirement will continue and it is therefore useful to examine it.

\footnotetext{
${ }^{45}$ Regulation 5(2)

${ }^{46}$ Indeed, law firms are precluded from being companies; even the recent adoption by some firms of the new form of Limited Liability Partnership (LLP) was seen as a major step.

${ }^{47}$ Notably in their reporting, or lack of it, of suspicious transactions: in the annual "league table" of sectors by the number of suspicious transaction reports that each files, solicitors have come close to the bottom and accountants bottom of all.
} 
The requirement for additional regulation for money service operators and high value dealers is in response to a growing perception of their vulnerability to money laundering. That vulnerability has already been discussed in relation to bureaux de change in particular, but it should not be underestimated in relation to high value dealers either, particularly jewellers. On 9 March 2003, the Observer newspaper carried the headline "Drug gangs use London gem trade for cash" and the article went on to state, "Experts say diamonds are fast replacing more traditional methods of money laundering and that the trade is set to grow even more rapidly.”

To address this, the register of money service operators ${ }^{48}$ and dealers in high-value goods is set up and it will henceforth be a requirement, in order to operate as such a business, to be listed on it. Failure to register will not be a criminal offence, but it will render the person liable to a Customs penalty of up to $£ 5,000 .^{49}$

The application for registration is detailed. It must be in such form as HM Customs \& Excise prescribe and in must in any event contain the following information:

- the name of the applicant and (where different), the name of the business;

- his VAT registration number or, where the person / business is not registered for VAT, any other reference number that HM Customs \& Excise allocate $^{50}$;

- the nature of the business;

- the address of the business: where there is more than one branch or premises, the addresses of all of them must be provided;

- details of any agency or franchise agreement relating to the business, together with the names and addresses of all relevant principals, agents, franchisors or franchisees;

- the name of the MLRO (if one exists).

In addition to this, the application must also state whether any person concerned in the management, control or operation of the business has been convicted of money laundering, as defined by either sections 340(11) of the Proceeds of Crime Act 2002 or section 18 of the Terrorism Act 2000, or of any offence under the Money Laundering Regulations.

At first glance, the latter, an offence under the Money Laundering Regulations, appears very wide. The reference to a conviction, however, makes clear that it is not every breach of the Regulations that is to be declared, but rather only those which are criminal offences. These admittedly cover most of the requirements, namely to have proper antimoney laundering systems, to provide appropriate staff training, to obtain satisfactory

\footnotetext{
${ }^{48}$ Ie. bureaux de change, money transmission offices and cheque encashment businesses: see above.

${ }^{49}$ Regulation 20(1). This penalty may be imposed, not only for breach of the registration requirement but for any violation of the Regulations, including those for which a criminal prosecution may also be brought.

${ }^{50}$ VAT registration is only compulsory in the U.K. if the value of the business' "taxable supplies" in a given year exceeds $£ 56,000$ (VAT Notice 700/1). It is conceivable that in the case of certain small businesses, the annual value of such supplies will be less than this threshold amount and therefore that some may not be VAT registered.
} 
evidence of the identity of business counterparties, to keep proper records and to have in place proper internal reporting structures. They do not, however, include failure to register or even failure to co-operate with a Customs investigation into whether or not the above requirements have been complied with.

An interesting question concerns whether a conviction under the pre- $2003^{51}$ money laundering legislation will need to be declared. On one interpretation, it will not: a conviction under, for example, the Drug Trafficking Act 1994 is not a conviction under the Proceeds of Crime Act 2002. But it is arguable that such "old" offences are, in fact covered. Section 340(11) of the 2002 Act refers to offences under section 327-329 of the Act, to committing such offences as a secondary party (ie. through incitement, conspiracy, aiding, abetting, etc.) and also to an act which would constitute such an offence were it to be committed in the U.K. In general, the last of these has been taken to refer to acts committed abroad and of course it includes these. It could be argued, however, that, since any act which would have constituted a money laundering offence under the 1988 or 1994 Acts is covered by the 2002 Act, any conviction for such an offence at the time that those Acts were in force will be covered by section 340(11) of the 2002 Act. As such, on this interpretation, it will need to be disclosed under Regulation 10(2)(b)(vii) of the 2003 Regulations. It is suggested, however, that it is unsatisfactory to resort to such a complicated approach. It would have been a simple matter for those drafting the Regulations to have added a line, requiring disclosure of a money laundering offence under the Criminal Justice Act 1988 or the Drug Trafficking Act 1994. If nothing else, this would have provided clarity, never a bad thing in any legislation, either primary or secondary.

The same applies, at least to an extent, to convictions under the 1993 Money Laundering Regulations before the 2003 Regulations came into force. An earlier draft of the 2003 Regulations explicitly required such a conviction to be declared; this was not, however, carried over into the final version. Nonetheless, since any criminal breach of the 1993 Regulations would constitute an offence under their 2003 replacement, it is arguable that such convictions should, in fact, be declared. ${ }^{52}$

Where, after the application has been submitted, it becomes apparent to the business that it is incomplete or inaccurate, the business is required to send further information to the Commissioners of Customs \& Excise, remedying this. ${ }^{53}$

The Commissioners then determine whether or not registration is to be granted. Interestingly, they may only refuse registration if the requisite information has not been supplied or it appears to them that it is false or misleading. Regulation 12 is clear:

\footnotetext{
${ }^{51}$ Although the Proceeds of Crime Act was passed in 2002, it only came into force the following year.

${ }^{52}$ A parallel may be drawn with the requirement, under the professional conduct rules of the General Council of the Bar of England \& Wales, for an applicant for call to the Bar to declare any criminal convictions and thereafter to report any that he subsequently obtains. The Code of Conduct does not explicitly address the question of criminal convictions obtained outside the U.K., but in 1990, the then chairman of the Professional Conduct Committee, Mr. Gareth Williams, expressed the view that if they were serious, they should be reported.

${ }^{53}$ Regulation 11
} 
registration may be refused "if and only if" this applies. In other words, a jeweler, antique dealer or car dealer, for example, may freely admit that they have been convicted of money laundering and the Commissioners will have to grant them registration. ${ }^{54}$ This will mean that it is very much in the interests of such a business to admit to a money laundering conviction under the pre-2003 regime, whether or not it is actually required: such a conviction cannot be a bar to registration, while, on one interpretation, at least, failure to admit to it could be.

If (as, therefore, in most cases), registration is granted, a number will be issued to the business. As seen above, this number must be obtained, as part of the evidence of identity, by any business with which a money service operator conducts a financial transaction, although the same requirement is not imposed on persons transacting with dealers in high-value goods. Part III does not end here, however; it gives to HM Customs \& Excise a wide range of investigatory powers in relation to such businesses which it does not have in a more general context.

But, as discussed above, dealers in high value goods need only be registered (indeed, they are only covered by the draft Regulations at all) provided that they conduct transactions with a minimum value of $€ 15,000$ and, furthermore, that they do so in cash. It will therefore be an entirely legitimate option for a jeweller, for example, only to accept cash for items with a value of up to, say £5,000. This is not uncommon: one jeweller consulted stated that the maximum price they will accept in cash is $£ 3,000$ and then only from a customer who is well-known to them personally. (Effectively, they will only do so from one who is a personal friend.) Even below this amount, the preferred method of payment is by debit card; after that, it is by credit card. This policy was not, however, so much motivated by compliance with the money laundering regulations - although, of course, it achieved that - as by the desire to avoid the practical problems of carrying large amounts of cash through the streets to the bank.. Some other jewellers did, they confirmed, adopt a different policy and accept cash for articles with a much higher value but their comment was that such jewellers were "less elegant".

If this view persists, it is likely to be a further pressure on legitimate dealers to move away from cash for high-value items and towards payment by such means as debit and credit cards: this will avoid not only a suspect reputation but the inconvenience of completing a highly detailed application. This in turn will result in the legitimate sector not being registered (because it does not need to be) and hence even greater scrutiny being applied to others. This will without question be welcomed by both government and law enforcement and indeed may well prove to be a valuable development. As has been argued above, continued dealing in large volumes of cash, especially in sectors prone to be used for money laundering, may well be less than ideal.

The disadvantage to the new system, however, is the difficulty of its enforcement. A jeweller that does not conduct transactions in cash above the $€ 15,000$ threshold will not need to be registered. One that does, will. But do Customs \& Excise really have the resources to check every jeweller's accounts - at all, let alone on a regular basis? It could

\footnotetext{
${ }^{54}$ The situation is not quite as simple as regards bureaux de change: see below.
} 
be argued that they do, by virtue of their separate role of collecting VAT. A VAT inspection by Customs \& Excise involves the examination not only of the business' accounts but also all its bank statements. While the former may merely record amounts received and amounts paid out and will not always record whether a payment received was in cash, by cheque or by credit card, the business' bank statements will show those details. Unless there happen to circumstances arousing Customs \& Excise's suspicions, however, such inspections are quite rare: a business reported that in the 16 years that it has been trading and registered for VAT, it has been inspected only once. A dealer could, therefore, take the view that the probability of being caught dealing in cash above the $€ 15,000$ limit is relatively low. This, combined with the relatively small consequences of being caught, namely a $£ 5,000$ penalty that does not even constitute a criminal conviction may mean that the "less elegant" simply continue to operate in the shadows.

The question then arises: should all high value dealers be registered, irrespective of the value of their transactions and how they execute them? This is unlikely to be popular: small jewellers that operate entirely legitimately will not welcome being required to fill out a long, complicated, detailed application. It will remain to be seen whether the vulnerability of the high value dealer sector is such as to override such inconvenience. This issue, in turn, is likely to be influenced by the view as to how effective, or otherwise, the registration requirement has proved to be. If its effectiveness turns out to be limited, the view may be taken that it is better to remove the system of registration for high value dealers. Instead, the specifically anti- money laundering provisions of the Regulations, ie. the requirements for identification, etc., could be imposed on them whenever a transaction is above a certain threshold. The test would be the value of the transaction, not the means by which it was undertaken. The threshold would probably, at least to start with, be the standard $€ 15,000$ of the Directive. Since, however, this would not address the problems discussed above in relation to cash transactions, there might be an argument, notwithstanding the drawbacks, for imposing a lower threshold where transactions are in cash. This might be as low as $£ 1,000$, although, if a sufficient proportion of the industry pressed for a higher amount, it could be, say, £5,000. It would in any event seem difficult to justify a threshold higher than this if significant progress is to be made in preventing the jewellers' and similar sectors from being an easy means of laundering criminal property.

As mentioned above, the situation in regard to bureaux de change is slightly different. They, like dealers in high value goods, and indeed like other types of money service operators, are required to register with (for the moment) HM Customs \& Excise. But in addition, they are required to notify the Financial Services Authority. Regulation 25 requires all persons authorized to carry on a regulated activity to inform the FSA if they propose to carry on the business of running a bureau de change. This is a significant requirement since, although a previous conviction is not capable (provided that it is disclosed) of being a bar to registration with HM Customs \& Excise, it is certainly capable of persuading the FSA that the person concerned is not a fit and proper person to carry on a regulated activity, particularly one that is well recognized to be a popular means of money laundering. In consequence, the FSA may well refuse or withdraw 
authorization either to operate a bureau de change or, very possibly, engage in any regulated activity whatsoever.

It should be noted that this provision only applies to bureaux de change: money transmission and cheque encashment offices are unaffected. In practice, this distinction is of limited importance, since, at present at least, businesses providing money transmission or cheque encashment services typically also run, from the same premises, a bureau de change. That said, if, as is more than possible, running a bureau de change becomes barred to those with a previous record linked to money laundering, the sectors may become divided. This in turn may, of course, lead to Regulation 25 being extended to all types of money service operator: as with so much in the area of new legislation, one suspects that only time will tell.

\section{$\underline{\text { Conclusion }}$}

To conclude, much of the 2003 Regulations builds on the 1993 provisions that came before them; in many ways, the only real changes are those prescribed by the 2001 Directive. The emphasis on merely implementing the Directive has meant, however, that none of the drawbacks of the EU provisions have been avoided in the U.K. Most strikingly, dealers in high value goods are subjected to quite complex requirements, which go beyond those imposed on most other sectors, yet only if they deal in cash and then above quite a high threshold. Since they have been identified as a sector particularly vulnerable to money laundering, it is right that they should be covered by the Regulations, but it would be more useful to have them covered in all circumstances, albeit with particularly strict provisions where they do deal in cash. Similarly, stricter provisions should apply to cash transactions in all sectors covered, not merely some of them. Linked to this, it makes considerable sense for the thresholds, which trigger certain of the requirements, to be stated in sterling rather than in euro, at least where businesses outside the financial sector are concerned.

The registration provisions are a major innovation, albeit ones which apply, again, only to certain sectors. It is notable that, provided that businesses disclose fully all the information required of them, registration cannot be refused. The consequence will be that such businesses, if they do breach the main requirements, let alone engage in money laundering itself, will be subject to increased surveillance rather than an attempt to keep them out of the industry; this may well be the very purpose of the system of registration. The future may not be so much of strengthened control as of improved intelligence, following the trend of using business as an assistant, willing or otherwise, to law enforcement. 